\title{
OLEG SUŠA
}

\section{SOUČASNÁ EKOLOGICKÁ KRIZE A RIZIKO ZESPOLEČENŠTĚNÍ PŘíRODY}

(Ke krizi filozofických základů teorie vztahu společnosti a přírody v moderní kultuře)

Současná historicky unikátní ekologická situace globálních změn v přírodních podmínkách života lidí a lidských společností se svojí složitostí, rozsahem i dopadem stává podle názoru řady specialistů soudobé vědecké komunity historicky bezprecendentním fenoménem. Percepce této situace vyvolává jak specifické společenské vědomí rizika spojeného s moderní industriální, růstovou trajektorií evoluce globálních společností, tak pochybnosti či revize dosud běžných metafor kulturní legitimizace této evoluce - pojmů pokrok, racionalizace či modernizace, zakládaných převážně na jisté, technicky pojímané představě o vztahu společnosti a přírody - jako panství, kontroly společnosti a člověka nad př́rodou, jejichž produktem je rostoucí přivlastňování, osvojování, vylepšování, humanizace a „zespolečenštování (Eder 1988) prírody. S historickou jedinečností současné ekologické situace začínáme jinak chápat též historickou jedinečnost industriálních, moderních společností s jejich institucemi a evoluční dynamikou změny a transformace. Reflexe této situace ve filozofii, sociologii a dalších vědách o člověku - jestliže se má kriticky distancovat od oslav této sociokulturní evoluce při respektování nebývale globální a složité dimenze rizika globálních ekologických důsledků téže evoluce - se musí rozejít s explicitní i implicitní afirmací ekologicky bezstarostné a destruktivní expanze jakožto „přirozeného“ či samozřejmého cíle univerzálního procesu sociální evoluce a modernizace a zaměřit se na problematickou víceznačnost evoluce interakce člověka a př́rody, jež měla a má sociálně zprostředkovanou podobu.

\section{KRIZE KULTURNÍ FORMY PANSTVÍ V HISTORICKÉ EVOLUCI VZTAHŮ SPOLEČNOSTI A PŘ́́RODY}

Z hlediska historické evoluce lidských kultur měla interakce člověka $\mathrm{s}$ př́rodním prostředím jako přirozenou základnou přežití vždy své specifické důsledky a dopady v podobě lokálních a regionálních změn, krizí či devastací, způso- 
bených lovem, sběrem, kácením a klučením lesů, zemědělskou kultivací, osídlením, rozvojem sídel a hlavně měst atd. Až do 20. století však nedocházelo k tak rozsáhlému celoplanetárnímu ohrožení př́rody, biosféry, atmosféry - Zemi se dařilo v té či oné mîre spontánně obnovovat rovnovážné vztahy vzájemné závislosti jako rozsáhlému celku - přitom však uzavřenému systému. Přestože byl člověk vždy součástí tohoto celku a závisel na něm, byl jako jediný biologický druh schopen jej narušit a zničit v důsledku své schopnosti technicky do něho zasahovat. Historicky stálým problémem lidských společností byl způsob, jak vyrovnávat své různé potřeby se schopností ekosystémů unést tyto zásahy (Ponting: 17). Až teprve v posledních dvou staletích došlo jak k rychlému př́růstku lidského obyvatelstva, tak k vystupňování spotřeby světových zdrojů a rychlosti technických inovací a jejich účinnosti. Lidské zásahy byly motivovány překonáním rizika nouze, omezení prostředím a zvyšováním možností voleb (kontingencí). $Z$ hlediska lidí a jejich společností byla rostoucí schopnost kontroly a modifikace prostředí při vzrůstající kontingenci v řešení problémů pokrokem, ale $\mathrm{z}$ hlediska ekologické situace je tento proces evolučním sledem stále složitějších a environmentálně škodlivějších způsobů uspokojování lidských potřeb. Proces industrializace ve světovém měřítku nadále pokračuje, postindustriální změny jsou dílčí a jsou spojeny s přetrváváním průmyslové výroby a expanzí spotřebovávání přírody, včetně energie. Deindustrializace je regionální záležitostí států, nikoli moderní společnosti jako celku. Soudobá environmentální situace je ovlivněna také mezinárodními vztahy moci a závislosti, soutěže, konfliktu a spolupráce, velkou nerovnoměrností v rozdělování světové moci a bohatství, jež mají své kořeny ve vývoji posledních pěti století a komplikují koordinaci strategie řešení nebo prevence globálních obtiží a limitů. Vážné limity hrozí lidským společnostem ze strany globální environmentální změny regulačních procesů, nedostatku vody, půdy, vzduchu a snižování biodiverzity. I kdyby současné úrovně spotřeby v evropských státech a v USA nevzrostly, odhady vcelku pochybují o tom, že se vůbec někdy podaři zbytku lidstva opakovat proces industrializace a dosáhnout této úrovně. To kontrastuje s aspiracemi rozvojového světa po modernizaci a industrializaci $v$ intencích evropského sociokulturního modelu a navíc tyto země již jsou na této cestě. Kdo je odvrátí od této cesty a kdo napraví důsledky devastace, znečištění a vyčerpání zdrojů, za něž je odpovědný moderní průmyslový svět? Globální situace environmentální změny $\mathrm{k}$ horšśmu podněcuje mnoho otázek o fundamentech způsobu života industrializované společnosti, nikdo však není s to $s$ jistotou předvídat další budoucí dopady a rizika: globální oteplování pokračuje, skleníkový efekt i znečištění, populace rostou a světová produkce potravin klesá (Ponting: 401-406).

Globální oteplování poprvé v dějinách ukazuje celosvětový dopad ignorování ekologických mezí či omezení lidskými společnostmi. Kulturní mýty o nezávislosti kultury a společnosti na přírodě se ukazují jako iluze s nedozírnými následky pro Zemi i pro člověka. Zdá se také, že historický čas člověka - měřeno spotřebováváním a destrukcí prírodních ekosystémových základů společností - se velmi zrychluje, či snad dokonce zkracuje v neprospěch obou partnerů či zdánlivých konkurentů, tj. př́rody 
i člověka. Ekologická krize se proto jeví jako nové kulturní ,,memento mori“ globální civilizace konce 20. století.

Z hlediska kulturních základů relativní vyváženosti interakce společnosti a př́rody lze soudit, že spîse většina kultur či civilizací v tzv. předindustriálních dějinách Země si dokázala - i přes agresívní zásahy do prostředí - vytvořit výrazné duchovní, technické, náboženské a mravní předpoklady udržitelné „,kooperace či koevoluce“ s cykly přirozené přírodní reprodukce. V bilancování ex-post byly snad ,agrární společnosti“ zpravidla více opatrné - ve smyslu většího uvědomění limitovanosti lidské existence - či trvale udržitelnější než městské, průmyslové, moderní společnosti. Oba typy společnosti vytvořily ve své evoluci odlišné kognitivní postoje k ekologické interakci s přírodou, Zemí. Venkovská společenství mívala jak fyzicky, tak duchovně a hodnotově tradiční formy „moudrosti“ v podobě sociálního povědomí bezprostřední závislosti lidí na Zemi. Tradice lidových kultur dodnes dokazují úzkou provázanost existence člověka s jeho přirozeným životním světem, polem, lesem, zvî̃aty, cykly ročních obodobí, pohrom a přírodních katastrof, záplav, sucha, neúrody, nouze, tělesné smrtelnosti člověka. Městská prostředí od počátku opevněná, tudíž fyzicky oddělovaná od okolní volné krajiny hradbou (oddělení, jež mělo vojensky, tj. mezilidskou agresí, motivované určení), žila uvnitř těchto hradeb $\mathrm{v}$ uměle vytvářeném, tj. sociálně vytvářeném technickém prostředí. Toto sociálně vytvářené prostř̌edí „druhé přírody" společně s trhem zboží a služeb, informace a vědění podporovalo sociální vědomí (a také tvorbu kulturnich mýtů o vnějškovosti př́rody jako prostředí - „okolo" hradeb) o sociální nezávislosti společnosti, lidských individuí a myšlení na př́rodě. To mělo své četné projevy v evropské kultuře, filozofii a vědě, jež se od renesančního humanismu rozvíjely právě $\mathrm{v}$ městském prostředí rostoucí sekularizace názoru na svět. Město navíc postupně ovládlo silou svých trhů komodit i informací venkov, pohltilo vesnickou společnost i s jejími tradičními institucemi sociální kontroly a stavovské sociální struktury lidské ekologie. Toto městské ovládnutí učinilo z venkovské společnosti i z celé přírody hlavně zásobárnu zdrojů potravin, i surovin pro průmyslovou výrobu.

Zárukou moci se stala kontrola nad zdroji růstu. Legitimizující kulturní metaforou - heraldickým klenotem - této moci a kontroly se stal racionalizující mýtus o nezávislosti vědění a osvobozující moci, vítězící nad závislostí poddaných na jejich pánovi, nad legitimitou tradičních mýtů stâbility lidských věcí posvěcenou Bohem a Církví Svatou - a přitom rovněž nad Přírodou. Tomu napomáhala též filozofie subjektivní racionality, v níz je rozum umístěn v subjektu, svoboda podmíněna nezávislostí nazírajícího subjektu na okolí, na ostatním světě. Metafora ,venkovské idiocie“" měla vyjadřovat despekt $\mathrm{k}$ moci ,staré společnosti“ a jejích elit - ale také nechut akceptovat jakékoliv fyzické i metafyzické limity tradiční „trvale udržitelné“ víry v ekologickou závislost na ,přirozeném, prúrodním“ rádu, v limitech přírodního řádu i lidského řádu tradic, vyjadřovaných kupř. v náboženské pokoře. Idea limitů se stala (a je i dodnes) terčem alergických výpadů „,moderního humanismu“, ekologická závislost byla sociálně překonávána jako řešení mocenského problému „Boje 
s něčím, proti něčemu a někomu“. Boj proti utiskovatelům, „třídám zahálky“ či „vykořistovatelům“, boj „za svobodu“ etc. byl zároveň bojem proti moci a o moc Př́rody nad ní.

Limity jsou dodnes chápány jako omezenost, nouze, bída v politickém, ekonomickém i duchovním smyslu - např. R. Dahrendorf komentoval modely Ř́mského klubu jako „limitovanost myšlení v pojmech limitů“ (Dahrendorf: 1992: 206) ... řada sociologů, ekonomů, politologů vidí v ekologickém myšlení a kritice reakční konzervativní „návrat na stromy“, nebo alespoň do „Temného Středověku“. Moderní myšlení takto bohužel ekologicky necitlivě, až protiekologicky ztotožnilo ideu svobody, nezávislosti, emancipace ve společnosti a mezi lidmi s mýtem zdánlivé nezávislosti a moci nad Přírodou. Odtud čerpá také soudobá kritická teorie sociální ekologie své závěry o projekci vztahủ panství z vnitrospolečenské interakce mezi lidmi na vztahy a interakce společnosti a př́rody (např. srv. Bookchin, Merchant, Eckersley).

\section{MOC, VĚDA, TECHNIKA A STŘíDÁNÍ SOCIOKULTURNÍCH MÝTŮ}

Křestanská kulturní tradice s artikulací ambivalentního, dvojího vztahování člověka $\mathrm{k}$ prrírodě, jež by snad bylo možno nazvat spirituálně-instrumentálním, v závislosti na interpretacích příslušných pasáží Písma a teosofických i teosociologických výkladů, napřr. člověk jako uživatel pán pověřenec" Boha-Ducha Stvořitele, který mu uložil správu pozemského stvoření a zároveň jeho služebník, jenž respektuje v pozemském stvoření také jeho i svého Stvořitele (Leiss, Attfield).

Mýtus stvoření podle Genesis se v historicky mnohotvárných a kontradiktorických (tj. odkouzlení i zakouzlení, diferenciace i dediferenciace moderního i romantického a protimoderního atp.) procesech modernizace západoevropského kontextu postupně transformoval v nový sociální mýtus o rostoucí moci lidstva nad Přírodou a jejími silami v kontextu industriálně technovědní kultury s př́značným racionalistickým názorem na neustálý růst nezávislosti na limitech Přírody jako prostředí, růstu moci v důsledku emancipovaného Rozumu a ,svobodnou či ke svobodě směrující“ Společnost. Došlo též k záměně významů „konzervačního“ a „,konzervativního“.

Mýtus Božího Stvoření a místa člověka v něm na bázi spirituálního propojení a mravní smysluplnosti Kosmického řẩdu, který také implikoval určitou sebekontrolu, byl nahrazen demytologizující materialitou (,odkouzlením “M. Webera), kognitivní skepsí a posléze instrumentálním mýtem sociálněpolitické a ekonomické sekulární spásy. Tyto změny vyrostly právě z městského typu sociokulturního prostředí.

Duch změny - filozofické, vědní, průmyslové i politické revoluce modernizačních procesů - znásobily vědomí a pocit nezávislosti člověka a společnosti na přírodě a nastolily normativní systém regulace sociálního jednání založený na dualizaci světa (světa kultury a světa př́rody) a na oddělení lidské společnosti a přírody - jako technicky kontrolovaných prostředí. Mýtus duchovní spásy byl v hodnotových soustavách nahrazen mýtem instrumentální manipulace obou světů, na základě so pro- 
dukce vědění, s využitím kongnitivně institucionalizovaných soustav vědeckých zákonů. Instrumentální vědění nazíravé přírodovědy je sociální konstrukcí, jež zároveň (uměle) konstituuje svět přírody zbavené morálních a estetických hodnot, které byly nahrazeny pozitivním věděním, a jež umožňuje technické zásahy do přírody. ,Druhý“, mimolidský svět, svět přírody a přírodní reality je odtud rovněž sociálně konstruovaným světem abstraktních zákonů, principů, mechanismů, laboratorních a technických experimentů. Vztah člověka $k$ přírodě je v moderní civilizaci zprostředkováván Technikou, jejímž hlavním smyslem, posláním je kontrolovat, ovládat. Moc tohoto sociálního vytváření přírody a definice jejího pojmu $\mathrm{v}$ jazyce vědy komunikovaném do společnosti a $\mathrm{z}$ nich vyplývající zprostředkování interakce společnosti a př́rody způsobují, že Příroda se takto jeví jako součást Společnosti, jako přivlastněná, zespolečenštěná příroda (Dreitzel, Eder 1988).

Pojem zespolečenštění přírody má dvě roviny: pruní je materiálnětechnické rekonstruování a ekonomické „spotřebováváni“", druhou je reflektovaný sociální vztah a jeho symbolickokulturní definice. Obsahem kulturní definice Přírody může být ekonomická hodnota Přírody jako zboží, estetická hodnota přírodní krásy nebo morální a náboženská hodnota. Tyto hodnotové kulturní obsahy mohou být v rozporu s ekonomickou hodnotou a tento rozpor je jádrem hodnotové roviny současných environmentálních konfliktů v moderních společnostech.

$\mathrm{Z}$ tohoto dvojdomého zespolečenštění přírody vyplývají dva aspekty charakteru sociálního vztahu k přírodě: a) produktivismus - technické využití vědění, Vědy, a b) symbolická komunikace kulturních významů a symbolů přírody. Odkouzlený obraz Přírody je symbolickým obrazem, který byl v modernizaci využíván jak pro instrumentální utilizaci (technickou kontrolu a kontingence zvyšování zisku), tak i pro moderní sekularizovanou kulturní komunikaci s hodnotovou symbolizací, např. štěstí jako bohatství, materiální blahobyt, spotřeba, nebo „nutnost“ byrokratizace výkonu autority a správy na bázi „vědeckého rozumu“ a disciplinizace lidí institucemi v zájmu „pokroku a pořádku“, jež jsou hodnotově indoktrinovány socializačními procesy do kulturního vědomí členů společnosti.

Sociální legitimita technicky zaměřené vědy byla založena na sekulárním pojmu Pokroku, jenž byl měřen, verifikován právě stupněm „ovládnutí prírodních sil“, ,panstvím nad přírodou". Ovšem prastarý strach z mocných sil přírody překonávaný agresívním úsilím o její opanování je na konci 20. století doplňován strachem ze sil techniky, jež se jeví jako nekontrolovatelná, živelná, kvazipřírodní síla. Genetické technologie mohou vyústit v produkci umělých lidí, zbavit člověka specificky lidského, vojenské technologie ovlivňují míru rizika samotného přežití, genetické produkty a vedlejší produkty biotechnologických manipulací mohou rozvrátit biosféru se stejným bumerangovým efektem na člověka, jako je tomu u znečištění, odpadů, vyhubených druhů atd. Kognitivní jistoty vědy se mění v nejistoty rizika - strach z neznámých sil přírody se mění ve strach z neznámých důsledků techniky.

Situace je komplikována právě historicky jedinečnou skutečností sociálně konstruované vědeckotechnické kontroly - panství společnosti nad přírodou. Př́roda tu 
fungujje a je společensky vnímána jako umělá, ,sociálně zlepšená“, zespolečenštěná, tzn. v podstatě jako technický produkt zbavený života a smyslu. Utilitarizovaná hodnota zespolečenštěné př́rody je ekonomickou hodnotou skladu surovin a zdrojů, proto je smysl ekologie vykládán v symbolickém kontextu hrozeb nedostatku, nouze je zaměněna za obsah a význam, smysl limitů (Ophlus, Anderson 1976).

Tato kontrola a obraz přírody vyvolávají obavy z konsekventní logiky technického procesu: důsledky panství společnosti nad přírodou v podobě důsledně umělého životního prostředí, kde nic není přirozeně prírodního původu (nevytvořeno člověkem), vedou k poškození prírody samé - a to nevratnému. Rozvoj technického prostředí a růst nevratného poškozování prostředí přírodního mají dnes globální dopady v komplexním procesu globální environmentální změny.

V této souvislosti nutno připomenout, že podstatou soudobé kritiky techniky je nikoli nefungování či špatné fungování (dysfunkce) techniky, ale právě její fungování ve smyslu Luhmannova „fungujícího zjednodušení", jež ovládáním prírody ovládá také nás (Nowotny: 578) a vystupuje jako autonomní technická moc nad lidmi (Winner). Destrukce prrírody je destrukcí člověka jako její neoddělitelné biologicko-fyzické součásti. Pro společnost tak vzniká otázka míry - proporce a hranic sociální konstrukce přírody, problém jak kontrolovat či korigovat důsledné důsledky dvojznačného panství nad přírodou. Toto panství, technická moc nad přírodou má dalekosáhlé důsledky pro přrírodu i pro samu lidskou společnost. Vzniká dvojsečná problematika posuzování výhod či vymožeností ,pokroku“ a nebezpečí rizik vyplývajících z narušení přírodněekologické rovnováhy v důsledku sociální, zejména technické konstrukce reality založené na vědecké ontologii nerozlišující mezi přirozeným a umělým a na manipulacích hmoty (nejen industriální produkcí objemů hmoty, ale také na míru, podle individualizovaného přání konzumentů, což bývá často hodnoceno jako ekonomický progres v uspokojení potřeb společnosti). V kontextu, v situaci abstraktního vědeckotechnického zpracování přírody - fenomenálního konstruování, rekonstruování a reprodukce - ztrácí moderní společnost stále více kontakt $s$ přírodou a rozklad přirozeného přírodního světa člověka a ostatního života na Zemi se proto jeví jako bezprecedentní modifikace krize ekologického kontextu lidstva.

Současná ekologická krize tak vyvolává palčivé otázky moci a mravní dilemata odpovědnosti za směry a cíle vědeckotechnického pokroku nejen $\mathrm{z}$ hlediska dopadů na přírodu jako na fyzické životní prostředí člověka, ale také dopadů na samo panství v podobě požadavku opanování technického panství, například společenské, morální, technické kontroly. Ekologická krize je historicky jedinečnou situací, nebơ vytvárí požadavek sebeovládání společnosti tím, že nastoluje zároveň imperativ kritické sebereflexe a seberegulace moci, jež se sama ve své mytické neomezenosti stává stále více sebedestruktivní. Sociologie by si měla v tomto kontextu klást takové otázky jako: Kdo je nositelem ekologické odpovědnosti? Co má být vědecky zkoumáno a technicky vytvářeno? Jak posilovat vědomí odpovědnosti a uskutečňovat „kontrolu technické kontroly"? 


\section{EKOLOGICKÉ RIZIKO A PROBLÉM ODPOVĚDNOSTI}

Ekologická krize je v kontextu moderních společností a moderní kultury reflektována a komunikována jako soubor rizikových důsledků vědeckotechnického ovládání př́rody. Pojem ekologické krize se stal součástí jazyka používaného v sociální komunikaci, součástí rétoriky environmentalistických, „zelených hnutî“, jazyka politiků, vědců i informačních médií. Obsahem rozmanitých sdělení o ekologické krizi, jež má prvořadý politický význam pro soudobé společnosti, a proto se stává politikem, je varování před dalším pokračováním sociálního jednání, jež nerespektuje rámec prrírodně- ontologických základů života společnosti. Protestní občanská hnutí vznikající od konce 60 . v let v nejrozvinutějších průmyslových společnostech Západu a zájem o komunikaci informace o rostoucích rizicích umělého sociálně, technicky konstruovaného prostředí i destrukci a devastaci mimolidského, přirozeného prírodního prostředí - vyjádřila nejen obavy a strach z techniky a technických hazardů, ale také nechut k zaplacení rostoucí „ceny“ za pokrok v podobě gigantického, exponenciálního růstu, expanze, zespolečenštění přírody. Občanské protesty ukázaly rostoucí nedůvěru ke schopnosti politických a administrativních institucí efektivně kontrolovat rizika důsledků technického ovládání světa přírody. Ekologické vědomí, resp. uvědomění se tak stalo jedním ze zdrojů pocitu širší krize civilizace - a to jak jejích prostředků, tak i cílů, hodnot, potřeb, smyslu. Zkušenost nových protestních sociálních hnutí ukázala jak potřebu alternativ, změn v hodnotách i institucích, cílech a potřebách ve směru ekologické seberegulace společnosti, tak i obtížnost při identifikaci sociálních oblastí odpovědnosti za cíle, prostředky i důsledky vědeckotechnického přetváření.

Při nastolení otázek sociální, resp. politické odpovědnosti a regulace ekologických rizik se ukázalo, že identifikovat tuto odpovědnost znamená oscilovat mezi jednotlivci a institucionálními organizačními kolektivitami. $V$ decizních procesech moderních byrokratizovaných a rozsáhlých aparátů není subjektem jednání individuum. $\mathrm{Z}$ toho však neplyne, že je tím plně zbaveno odpovědnosti - pocit odpovědnosti mohou rozvíjet jen jednotliví lidé (Zimmerli: 86). Na druhé straně - moderní věda jako hlavní kulturní arbitr pravdivé výpovědi o skutečnosti přírody a zároveň producent sociální konstrukce této skutečnosti - poskytuje hlavně návod $\mathrm{k}$ technické operaci, a nikoli kontemplaci, poskytuje znalosti, nikoli smysl. Věda neposkytuje lidskému jednání orientaci, jen kontrolu. Kulturní obraz odkouzleného světa nedává vědění o bytí přírody, nýbrž hypotetické a teoreticky relativní, tj. falzifikovatelné soudy o skutečnosti, jež umožňují pragmaticky její kontrolu a změnu. Normy veřejného jednání uznávají morální status lidské osoby, morální či estetické soudy o přírodě jsou osobní, soukromou záležitostí, nikoli normou pro společnost (Daele van den: 586).

Technická odpovědnost za důsledky použití vědeckého vědění, za jeho operacionalizaci, je delegována na sociální mechanismy individuálních voleb, trhu, profesionálních praktik v kontextu kvaziautonomních segmentů či subsystémů ve společnosti. Problémy ekologického rizika vznikají především ve sfére vědy, výzkumu, vývoje 
a ekonomiky (podnikánî), ale odpovědnost je delegována na subsystémy demokratické politiky a státní administrativy (Daele van den, Beck).

Odpovědné technické jednání by tedy mělo znamenat etiku zacházení s přírodou i s dvojznačností požadavků na jednotlivce: jedinec musí jednat podle internalizovaných norem v rámci požadavků určitých objektivních institucionalizovaných struktur a zároveň by měl jednat podle svého individuálnîho ekologického uvědomění a vnitřního svědomí či internalizovaných hodnot (např. ochrany prrírody nebo zdraví ve smyslu veřejných priorit, hodnot či práv).

Beck i Giddens používají při reflexi percepce moderních rizik pojmu „reflexívní modernizace ": rizika ztrácejí svou latentnost a jsou globalizována, tím také obtížně administrativou kontrolovatelná. Na druhé straně jsou rizika modernizace scientizována a veřejně komunikována, takže padají hranice mezi společností a př́rodou. Rizika destrukce př́rody nelze přesouvat ven, ,do prostředí" - externalizovat riziko, protože ,jejich univerzalizace průmyslem z nich činí ,sociální, politické, ekonomické a kulturní rozpory inherentní systému" (Beck: 154). Giddensova reflexívní modernizace vychází $\mathrm{z}$,,̌̌asoprostorové distancializace“ moderní mobilní, dynamické společnosti a stylů života, jež znamená rostoucí odcizení lidí od prírody a „víru ve vědecké, expertní systémy" v anonymních sociálních vztazích. Produkce, distribuce, šr̂rení nových vědeckých poznatků o světě vede $\mathrm{k}$ „reflexívním změnám“" ve společenských vztazích a k transformacím prúrody, vytrhuje sociální vztahy z jejich situovanosti v mistech (Giddens 1990:17,54). Globální ekonomické interdependence jednak snižují účinnost a vůbec i samu možnost „,politiky státu blahobytu“ v rámci státních ekonomik, jednak podněcují ekologické změny, jež ovlivní každého na planetě (Giddens:77). Ekologická a další rizika jsou globálně sdělována informačními technickými médii, avšak tím, že jsou sociální povahy, tj. jsou nadindividuální a obtîz̃ně lokalizovatelná ve svém rostoucím globálním dopadu, vedou jejich reflexe $\mathrm{k}$ dalšímu šîrení vědomí rizika jejich nekontrolovatelnosti a institucionální neprůhlednosti. Čím větší je informovanost laické veřejnosti v moderních rizikových prostředích, tím větši je uvědomění omezenosti expertních vědeckotechnických systémů, což vyvolává krizi důvěry laické veřejnosti v expertní systémy (Giddens: 130).

Na sociální povahu moderních rizik ohrožujících vnímání ontologické jistoty - převracené v nejistotu - upozornila již řada výzkumů. Lyttkens rozlišil napr. dva typy strachu a úzkosti spojených s riziky: existenciální úzkost a strukturální úzkost v závislosti na sociálních faktorech. Nejen technické riziko a jeho negativní ekologické dopady na prírodní prostředí, ale také prostředí soutěživé společnosti s ústřední hodnotou peněz, životního úspěchu měřeného ziskem - vyvíjí tlaky na ohrožení hodnot a potřeb ontologické jistoty vyvoláním úzkosti, zda jedinec obstojí v soutěžení, zda budou dostatečně „,výkonni““, „úspěšni“ atd. Podobně rostoucí globální ekologická rizika a hrozby působí na frustrace víry v pokrok, blahobyt a jistoty technickoekonomického růstu i nové techniky určené k odstranění rizik - nap̌r. zdravotních, ekologických. Nové techniky, nové zákony neruší nikterak nekonečný proud dalších a nových rizik (Lyttkens: 119). 
Pocity rizika, jež vyplývají př́ímo či nepřímo z vědy a techniky, nejsou doprovázeny růstem pocitů jistoty a bezpečí. Reflexe rizika - její scientizace - (Beck), jež implikuje osvíceneckou víru v expertizu (Giddens), využívá v moderní společnosti především vědní a technické expertízy - odvolávání se na vědeckou autoritu je ustavenou kulturní normou (Birnbacher). Vedle vědeckých soudů a jejich kritiky, tj. kritické sebereflexe vědy jako nutné podmínky jejího dalšîho rozvoje (Beck: 155), vědeckých soudů ,jistoty nejistot" vznikají však také laické, populární soudy, motivované úzkostí a strachem $\mathrm{z}$ toho, čemu jednotlivci a skupiny nerozumí, s typem soudu ,Je to nebezpečné" (Birnbacher: 139). Uvedená jistota nejistot - zvyšuje psychologické pocity ,nevyhnutelnosti žít s nebezpečími, která jsou mimo naši kontrolu nejen individuí, ale také velkých organizací - včetně soudobých států .takže.." za globální rizika moderny nejsou odpovědni ani jednotlivci, ani skupiny" (Giddens: 131). Giddens nabízí taxonomii adaptivních reakcí na nejistoty rizika: 1 . pragmatickou adaptaci politiky strategické výhody, žití ze dne na den, kdy dočasné zisky jsou to jediné, v co lze doufat, i když za cenu hlubinné úzkosti; 2 . trvající optimismus osvícenecké víry v pokrok rozumu i přes aktuální hrozby (projevují ho někteří vědečtí experti kritizující např. ekologické scénáře katastrof $z$ pozice víry v nalezení sociálních a technických receptů na řešení globálních problémů - věda nabízí hlavní zdroje dlouhodobé jistoty); 3. cynický pesimismus, který vyplývá ze stálého kontaktu se strachem z vysoce nebezpečných důsledků rizik a s jejich hrozbami, avšak zároveň je cynismem ,černého humoru", který emocionálně neutralizuje pesimismus a vede k oslavě momentálních požitků, a konečně 4 . radikální angažovanost s praktickou snahou potýkat se $s$ příčinami ohrožení, jež věří, že vědomí ohrožení by mělo mobilizovat k omezení dopadů anebo jejich překonání. Tato víra je optimistická a je spojena více se zápasem než s vírou v racionální analýzu a diskusi. Jejím hlavním hybatelem je sociální hnutí, soudí Giddens (Giddens: 137).

Ekologická hnutí a radikální směry ekologické filozofie a etiky operují především s expozicí non-racionálních, obtížně kalkulovatelných anebo vědecky měřitelných hodnot, jež jsou moderními riziky ohrožovány". Nejde jen o lidské zdraví a psychické škody, ale také o neantropocentrické hodnoty biosféry, její destrukce a ohrožení budoucích generací, ještě nenarozených živých (nejen lidských) bytostí, které nelze monetárně vyjadřovat a které mají inherentní (instrinsic) hodnoty pouze metafyzicky zdůvodnitelného bytí nepoškozené „přírodní" nebo ,přirozené" př́ŕrody. Jde o hodnotu celku, společenství, planetární biosféry, v níž participují jednotlivé druhy a jedinci (Attfield: 149). Ideál př́rody jako „divočiny“ má symbolizovat biologický řád nezávislý na sociálním řádu, celek, jenž má neinstrumentální hodnoty pro všechny pozemské tvory, nejen lidi. Místo tradiční kulturní symboliky antropocentrismu vtělené do moderní techniky a byrokraticky unifikující kultury industriální expanze ovládání světa je vypracovávána nová kulturní symbolika biocentrismu, která konfrontuje moderní centralizujicí princip unifikace světa s principem pluralitní rozmanitosti, princip mocenského ovládání s principem tolerance a koevoluce. 


\section{EKOLOGICKÉ RIZIKO, KRIZE A POJMY KOEVOLUCE A POKROKU}

Z existence moderních rizik technického ovládání světa, který je „socializován“, vyplývá „existence politického katastrofického potenciálu“, nebợ není možné rizikově neutrální jednání - lze provádět rozhodnutí s větším nebo menším rizikem v technické politice, výzkumném programu, strategickém managamentu, hodnotit a oceňovat pro a proti při vývoji, realizaci a zavádění nových technik. To implikuje konsekvencialistickou etiku „hledání nejmenšího zla“ v podobě soudobých nástrojů Technology Assessment či Risk Assessment a jejich korigování etickým hodnocením techniky jako přijatelnosti určité volby z hlediska přijatelnosti určité techniky (Birnbacher: 145-146).

Z percepcí adaptivních reakcí na existenci moderních rizik v př́padě globální environmentální změny vyplývá prohlubující se hodnotový konflikt mezi dvěma kulturami moderny, jež implikují rozporné procesy - odkouzlení a zakouzlení, diferenciace a dediferenciace (Tyriakan 1992: 78-96), kdy nová koncepce a symbolická definice přírody jako by požadovala novou reintegraci lidské společnosti, ,novou metafyziku“ a nové tabuizace pro lidské jednání. S tím je spojena i konfrontace pojmů evoluce a koevoluce. Podle Bouldinga má lidstvo ve světle globální ekologické krize opustit pojem evoluce ve smyslu 19. století jako boje o existenci a prežití silnějšího - jako monistické zjednodušení složité ekodynamiky a přitom respektovat jak přírodní prostředí, tak stupeň vývoje civilizace, lidské společnosti. Ekologové by neměli z ekologické evoluce, z biosféry, vylučovat člověka a společnost a sociální vědy i politika by měly globálně respektovat př́rodu. Koevoluci v ekodynamice si lze představit jako informační komunikaci v interakci, kdy vědění o prŕrodě by se mělo stát nejen prostředkem k cílům sebeudržování společnosti a kultury, ale také hodnotovým imperativem moudrosti $v$ působení společnosti na př́rodu. Pluralita hodnot (idejí i výtvorů techniky) v multiplicitě interakcí uvnitř společnosti, tj. v procesech ekonomické směny, politické a mravní koordinace, zároveň připouští jak mírný optimismus, tak katastrofy a morální dilemata. Člověka však nelze ,,vrátit do přírodního stavu“ (Boulding). Eder chápe pojem moderního zespolečenštění prŕrody jako dvojdomý fenomén moderní kultury, jenž implikuje dualistickou strukturu: a) racionalistického, vědeckotechnického obrazu prŕrody jako hmoty, prostředku, věci, který je legitimizací utilitaristického spotřebovávání přírody; b) uměleckého obrazu přírody, který přírodu chápe jako symbolické zboží - ,hodnotu“ přírody a její využití omezuje na morálně obhajitelná. Jsou-li dvě kultury jako dva typy racionality Habermasem zkoumané ve světě mezilidské interakce, tj. instrumentální a komunikativní - technická, přírodovědecká kultura na straně jedné, umělecká na straně druhé, extrémně protikladné (jak se mohlo zdát až dosud), neumožňují společné řešení současné ekologické krize jako problému rostoucí nerovnováhy ve vztazích mezi společností a přírodou. Podle Edera závisí rovnováha mezi společností a prírodou na kulturní formě společenské představy o př́rodě. Tuto představu je třeba založit na nikoli jednosměrném vztahu, který byl charakteristický pro ideu evoluce jako růstu 
moci společnosti nad př́rodou. Cílem je spî̃̃e takové pojetí koevoluce, v němž se společnost a příroda vyvíjejí společně v procesu zprostředkovaném kulturou. Dvě kultury moderny znamenají také dvojí způsob hodnocení přírody, jeho dualismus: na straně jedné kognitivní hodnoty, na druhé hodnoty estetické, na jedné straně dedukce a efektivnost, na druhé intuitivní vědění, estetické formy. Idea evoluce však historicky sehrála významnou ideologickou roli, byla sebedeskripcí a identifikací (jako určením identity) moderní společnosti. Zároveň plnila funkci při legitimizaci nadřazenosti a mocenské expanze moderní západní kultury v procesech globalizace (jako moc Subjektu nad Objektem-Zemí), jež je explikována tlakem společnosti na př́rodu a novou kvalitou tohoto vztahu - efektivitou, jež mění přírodní formy. Tento evoluční proces byl charakterizován zároveň jako „nutný a nevyhnutelný“" (Eder: 74).

Narůstající ekologická krize nutí dosavadní dualistickou moderní kulturu k novým reflexím a revizím, v nichž se jedná právě o redefinice „Přírody“ a „Pokroku“". V radikálně nových diskurzech zde probíhá soutěž dvou typů racionality - jako „dvou kultur v jedné“ - jako „dvou definic modernity v modernitě (Eder: 76) - jako „,reflexivní modernizace“ (Beck, Giddens) v rámci pokračujícího procesu modernizace moderních společností. Právě konfliktní diskurz kolem pojetí „Přírody“ tematizuje sociální konflikty produkované reflexí globálního ekologického rizika pochopeného konečně koevolučně, tj. jako rizika lidststíi i bytí.

Ederův pojem zespolečenštění přírody se pokouší o překonání panství, jednostrannost moci. Teoretické re ešení diskrepance mezi „,kulturou pro zisk“ a „kulturou jako komunikaci“", mezi monologem a dialogem spatřuje Eder nikoli v dualitě Habermasova Systému a Životního světa, nebot tímto způsobem je př́roda stále subsumována do sféry Systému ovládaného kulturou jako orientací na zisk, maximalizaci, efektivitu, a proto nelze přikročit k praktickému řešení ekologické krize. Navíc je nyní nezbytné uznat, že morálka prostupuje sféru př́rody ve stejné mî̃e, jako technika prostupuje sféru člověka. Proto již nelze oddělovat dvě pojetí „Pokroku“", tj. pojetí technické a morální. Problémem však je to, ,jak přelstít duplikace klíčových pojmů moderní kultury v situaci, kdy jsme ztratili víru v Pokrok natolik, že považujeme právě tuto víru za sebeiluzi““ (Eder 1990: 77).

Kritická revize pojmu pokroku, právě tak jako pojmu př́rody, je tudíz významným prostředkem, jak zachovat užitečnost sebedeskripce moderní společnosti v diskusi společenské vědy a tím také udržet její smysl.

\section{LITERATURA}

Anderson, Ch. H.: The Sociology of Survival" Social Problems of Growth, Homewood, ILL., The Dorsey Press 1976

Anderson, Ch. H.: To Govern Evolution. Further Adventures of the Political Animal, New York 1987 Alphandéry, P. - Bitoun, P. - Dupont, Y.: L'équivoque écologique. Edition La Découverte, Paris 1991 Attfield, R.: The Ethics of Environmental Concern, Oxford 1983

Beck, U.: Risikogesellschaft. Auf dem Weg in Eine Andere Moderne, Frankfurt a.M. 1986. The Risk Society, Toward the New Modernity (Transl. Ritter, Mark), London, Sage 1992 
Birnbacher, D.: „Ethische Dimensionen bei der Bewertung technischer Risiken“, IN: Lenk, H. - Maring, M. (hrsg.): Technik-Verantwortung. Guterbwagung - Risikobewertung - Verhaltenskodizes, Campus, Frankfurt, New York 1991

Bookchin, M.: The Ecology of Freedom. The Emergence and Dissolution of Hierarchy, Palo Alto, California, Cheschire Books 1982

Brennan, A.: Thinking About Nature. An Investigation of Nature, Value and Ecology, Georgia U.P., Athens 1988

Cotgrove, S.: Catastrophe or Cornucopia. The Environment, Politics, and the Future, Chichester 1982

Daele, van den, W.: „Kontingezerhohung. Zur Dynamik der Natur beherrschung in modernen Gesellschaften, IN: Zapf, W., 1991, pp. 584-603

Dahrendorf, R.: Moderní sociální konflikt, Archa, Bratislava 1992

Dreitzel, H. P.: "The Socialization of Nature. Western Attitudes towards body and emotions". In: P. Heelas and A. Lock (eds), Indigenous Psychologies. The Anthropology of the Self (pp. 205-223), Academic Press, London, 1981

Eckersley, R.: Environmentalism and Political Theory State University of N.Y. Press, Albany 1992

Eder, $K$.: Die Vergesellschaftung der Natur. Studien zur sozialen Evolution der praktischen Vernunft, Frankfurt, Suhrkamp 1988

Eder, K.: "The cultural code of modernity and the problem of nature" a critique of the naturalistic notion of progress", IN. Alexander, J. C. - Sztompka, P., eds.: Rethinking Progess. Movements, Forces and Ideas at the End of the Twentieth Century, London, Unwin a. Hyman 1990, pp. 67-87

Giddens, A.: The Consequences of Modernity, Cambridge, Polity 1990

Griffith, R.F. ed.: Dealing with Risk. The Planning, Management and Acceptability of Technological Risk, Manchester, Manchester U.P. 1981

Habermas, J.: Theorie des komunikativen Handelns, Bd., I, Frankfurt a.M., Suhrkamp 1988

Nowotny, $H$.: Naturbeherrschung, Technik und Gesellschaft. Einfuhrung, In: Zapf, W. Hrsg.: Modernisieirung moderner Gessellschaften, Frankfurt, New York, Campus 1991

Lasch, Ch.: The Culture of Narcissism, New York, Norton 1978

Leiss, W.: The Domination of Nature, New York, Braziller 1972

Lyttkens, H.: "Human anxiety", IN: Sjoeberg, L. (ed.): Risk and Society, London, Allen a. Unwin 1987, pp. $115-129$

Merchant, C.: The Death of Nature: Women, Ecology and the Scientific Revolution, San Francisco, Harper 1989

Ophuls, W.: Ecology and the Politics of Scarcity. San Francisco, Freeman 1977

Ponting, C.: A Green History of the World. Harmondsworth, Penguin 1991

O'Riordan, T.: Environmentalism, London, Pion 1981

Zimmerli, W. Ch.: „Verantwortung des Individuums-Basis Einer Ethik von Technik and Wissenschaft", IN: Lenk-Maring, 1991, pp. 79--89

Tyriakan, E. A.: "Dialectics of modernity: reenchantment and dediferentitation as counterprocesses", IN: Haferkamp, H. - Smelser, N. J., Eds.: Social Change and Modernity, Berkeley-Los Angeles-Oxford 1992, pp. 78-96

Winner, L.: Autonomous Technology. Technics out-of-control as a Theme in Political Thought, Cambridge, The MIT Press 1977 
The Contemporary Ecological Crisis and the Risk of Socialization of Nature

\section{Summary}

The contemporary global environmental change can be sociologicaly understood in connection with the risk, that occurs within the processes of socialization (i.e. material and symbolic appropriation) of nature by humans. This metaphor can be identified in terms of the relationships between society and natural environment as distinctively modern social, cultural construction based on the scientific image of nature with its dominant techno-economic and cultural symbolic levels.

The risks of ecological crisis today bring the questions of power and responsibility for the aims, directions and consequences of the scientific and technological development. This also leads to the questioning and revision of the very idea of social progress. The responsibility for the knowledge operationalization in modern societies is delegated to anonymous decision-making processes. The risk produced in the framework of quasi-autonomous segments of the enterprise, research and development are supra-individual, collective, social. They are mostly institutionally uncontrolled (and in this sense externalized) and producing controversial adaptive reactions by social actors.

Under such circumstances it is impossible, therefore, to separate any more the technological and moral aspects within the modern concept of "progress".

The claims of responsibility to avoid growing environmental threats and risk appeal for a renewed moral growth within social evolution and development in terms of sustainable development and co-evolution in harmony with the nature, not against nature. 